\title{
PENGLIBATAN NON MUSLIM SEBAGAI PEGUAM SYARIE DI MALAYSIA: SATU ANALISIS
}

\section{The Involvement of Non-Muslims As Syarie Counsel in Malaysia: An Analysis}

\author{
Khairul Azhar Meerangani ${ }^{1}$ \\ Syamsul Azizul Marinsah ${ }^{2}$ \\ Rushdi Ramli ${ }^{3}$
}

\begin{abstract}
The issue of the involvement of non-Muslims as Syarie counsel in the Shariah Court has triggered a debate among the public, especially involving Muslim scholars as well as Shariah and Civil legal practitioners in Malaysia. This is due to the actions of a non-Muslim woman lawyer who flled an appeal challenging the ban issued by the High Court to stop the practice as a Syarie counsel. This study aims to identify the background of the issue and its evaluation from the Islamic law perspective and the contemporary legislative provisions in Malaysia. The approach will involve analyzing the debate on Muslim scholars regarding
\end{abstract}

1 Ph.D Candidate, Department of Figh and Usul, Academy of Islamic Studies, University of Malaya, 50603 Kuala Lumpur, rahza_8811@yahoo.com

2 Ph.D Candidate, Department of Fiqh and Usul, Academy of Islamic Studies, University of Malaya, 50603 Kuala Lumpur, kehak@yahoo.com

3 Senior Lecturer, Department of Fiqh and Usul, Academy of Islamic Studies, University of Malaya, 50603 Kuala Lumpur, sufism@um.edu.my 
the involvement of non-Muslims as Syarie counsels and its evaluation based on the legal context and current reality in Malaysia. The prohibition of the involvement of non-Muslims was seen as crucial in preserving the relationship between religion in Malaysia and preventing any controversial disputes arising from the issue.

Keywords: Non Muslims, Syarie counsel, Shariah Court, Federal Constitution, Islamic Law

\section{PENDAHULUAN}

Perjalanan sistem perundangan di Malaysia yang mengamalkan konsep dualisme memperlihatkan kewujudan dua set perundangan yang diguna pakai secara serentak iaitu undang-undang Sivil dan undang-undang Syariah. ${ }^{4}$ Perlembagaan Persekutuan telah memperuntukkan sempadan dan bidang kuasa bagi setiap mahkamah bagi mengelakkan sebarang pertindihan dan pertikaian membabitkan perjalanan pentadbiran kedua-dua mahkamah tersebut. ${ }^{5}$ Namun begitu, sistem perundangan Syariah di Malaysia telah mencuri tumpuan pelbagai pihak, berikutan tindakan seorang pengamal perundangan, Victoria Jayaseele Martin dalam mempertikaikan tindakan Majlis Agama Islam Wilayah Persekutuan yang enggan memproses permohonannya untuk mendaftar sebagai peguam syarie. Lalu beliau memfailkan semakan kehakiman terhadap keputusan tersebut di Mahkamah Rayuan. Kontroversi timbul apabila pihak Mahkamah Rayuan memutuskan tindakan pihak Majlis Agama Islam Wilayah Persekutuan (MAIWP) adalah bertentangan dengan Seksyen 59(1) Akta Pentadbiran Undang-Undang Islam (Wilayah-Wilayah Persekutuan) 1993 yang hanya menetapkan mana-mana orang yang mempunyai pengetahuan mencukupi dalam Hukum Syarak boleh diterima sebagai peguam syarie. ${ }^{6}$ Pihak MAIWP seterusnya telah memfailkan rayuan ke Mahkamah Persekutuan dalam usaha mencabar keputusan yang telah dikeluarkan oleh pihak Mahkamah Rayuan. Isu tersebut akhirnya menemui noktah pada 24 Mac 2016 apabila pihak Mahkamah Persekutuan memutuskan bahawa tindakan pihak MAIWP

4 Perkara 121 Fasal (1A) menyatakan: "Mahkamah yang disebut dalam Fasal (1) tidaklah mempunyai bidang kuasa berkenaan dengan apa-apa perkara dalam bidang kuasa Mahkamah Syariah..."

5 Bidangkuasa Mahkamah Syariah dinyatakan dalam Jadual Kesembilan Senarai 2 (Senarai Negeri) Fasal 1 Perlembagaan Persekutuan.

6 Lihat keputusan Mahkamah Rayuan dalam kes Victoria Jayaseele Martin v. Majlis Agama Islam Wilayah Persekutuan \& Anor (2013) 6 MLJ, 649-650. 
tersebut tidak bercanggah dengan akta yang dinyatakan seterusnya mengekal keputusan Mahkamah Tinggi yang melarang keterlibatan peguam non Muslim untuk beramal sebagai peguam syarie. ${ }^{7}$

Beberapa kajian dan penulisan berkaitan isu penglibatan non Muslim sebagai peguam syarie di Malaysia telah dilakukan. Namun, pengkaji melihat penulisan tersebut hanya difokuskan kepada aspek teknikal sahaja tanpa diperincikan isu tersebut berdasarkan konteks hukum Islam dan perundangan semasa. Sebagaimana yang dilakukan oleh Naziree Md Yusof ${ }^{8}$ yang menilai pro dan kontra isu tersebut dalam memastikan survival perjalanan perundangan Syariah di Malaysia. Mad Zawawi Abu Bakar ${ }^{9}$ pula dalam membahaskan isuisu berkaitan peguam syarie di Malaysia turut menjelaskan ketidakseragaman undang-undang pentadbiran Syariah di Malaysia sebagai antara faktor yang membawa kepada tercetusnya polemik non Muslim yang berminat untuk beramal sebagai peguam syarie. Keperluan peguam syarie sebagai seseorang yang beragama Islam turut disentuh secara ringkas oleh Daud Muhammad. ${ }^{10}$ Penulisan yang menyentuh isu ini berdasarkan aspek hukum dapat dilihat menerusi analisis Taqwa Zabidi ${ }^{11}$ dan Zaharuddin Abdul Rahman. ${ }^{12}$ Namun, penulisan tersebut dilihat hanya memfokuskan perbincangan berkaitan hukum dan pandangan para ulama berkaitan penglibatan non Muslim sebagai peguam syarie serta kurang menyentuh aspek realiti semasa di Malaysia dengan lebih mendalam terutamanya membabitkan elemen perundangan. Walaupun keputusan perundangan berkaitan isu tersebut telah diselesaikan, namun masih wujud polemik yang membahaskan isu tersebut berdasarkan kecenderungan dan kepentingan pihak tertentu. Maka kajian ini perlu bagi menganalisis perbincangan berkaitan isu tersebut menurut kerangka hukum Islam dan

$7 \quad$ Lihat keputusan Mahkamah Persekutuan dalam kes Majlis Agama Islam Wilayah Persekutuan v. Victoria Jayaseele Martin and another appeal (2016) 2 MLJ, 315318.

8 Naziree Md. Yusof dan Aminuddin Mustaffa, 'Peguam Syarii Bukan Islam: Antara Pro dengan Kontra', Jurnal KANUN, 23/1 (2011): 84-106.

9 Mad Zawawi Abu Bakar, 'Isu-Isu Peguam Syarie di Malaysia', Jurnal Syariah, 11 (2003): 113-114.

10 Daud Muhammad, 'Peguam Syarie dalam Institusi Qada', Jurnal Hukum, 26/22 (2008): 137.

11 Taqwa Zabidi, 'Hukum Melantik Orang Bukan Islam sebagai Peguam Syarie,' Jurnal Penyelidikan Islam, 25 (2012): 195-218.

12 Zaharuddin Abdul Rahman, 'Bolehkah Peguam Syarie Non Muslim?', laman sesawang Zaharuddin.net, http://zaharuddin.net/senarai-lengkap-artikel/3/933bolehkah-peguam-syarie-bukan-muslim.html, dicapai pada 12 September 2016. 
perundangan semasa serta penilaian yang bersesuaian berdasarkan konteks semasa di Malaysia.

Kajian ini dilakukan menggunakan data-data perbincangan para sarjana klasik dan kontemporari bagi mendapatkan gambaran hukum yang lebih jelas dan bersifat semasa berkaitan isu ini serta teks-teks perundangan dalam usaha menyelaraskan isu tersebut dengan realiti semasa di Malaysia. Selain itu, pengkaji turut mengenal pasti latar belakang isu ini menerusi penulisan media secara elektronik dalam memastikan analisis yang dilakukan sesuai dengan konteks isu tersebut. Isu ini secara dasarnya melibatkan penghujahan dalam aspek hukum dan perundangan, namun asas-asas perundangan hanya akan disentuh secara ringkas di dalam artikel ini sebagai hujah sokongan bagi menjustifikasikan larangan keterlibatan non Muslim sebagai peguam syarie dalam konteks semasa di Malaysia. Hal ini kerana wujud pertembungan pandangan antara pihak berautoriti agama yang cenderung kepada larangan tersebut berdasarkan kepentingan semasa agama Islam di Malaysia dengan pihak persendirian yang mempunyai kepentingan tertentu dengan hanya berpegang kepada hukum asal penglibatan non Muslim sebagai peguam syarie sehingga menambahkan lagi kekeliruan yang telah sedia wujud dalam masyarakat awam. Maka, kajian ini bertujuan meneliti asas perbezaan pandangan tersebut serta merumuskan dapatan yang bersesuaian dengan konteks semasa di Malaysia.

\section{HUKUM PENGLIBATAN NON MUSLIM SEBAGAI PEGUAM}

Secara umumnya, tiada dalil yang benar-benar spesifik sama ada daripada al-Quran mahupun al-Sunnah yang menjelaskan persoalan pelantikan non Muslim sebagai peguam syarie. Maka, hukum berkaitan penglibatan non Muslim sebagai peguam syarie ini ditentukan berdasarkan dalil-dalil umum daripada al-Quran dan al-Sunnah serta pandangan para sarjana yang muktabar. Dalam aspek pembelaan dan pendakwaan, hujah daripada golongan non Muslim secara asasnya adalah diterima. Hal ini sebagaimana yang dinyatakan menerusi ayat yang berikut:

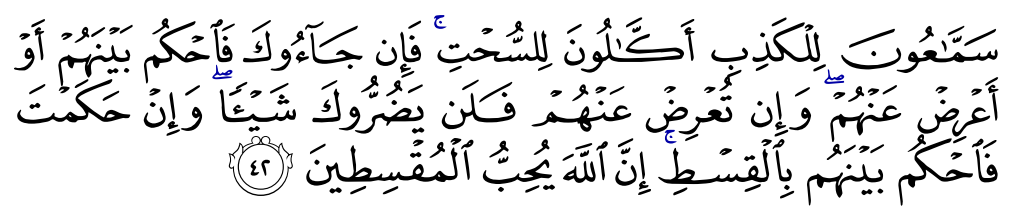

"Mereka itu adalah orang-orang yang suka mendengar berita bohong, banyak memakan yang haram. Jika mereka (orang Yahudi) datang kepadamu (untuk meminta keputusan), maka 
putuskanlah (perkara itu) di antara mereka, atau berpalinglah dari mereka. Jika kamu berpaling dari mereka maka mereka tidak akan memberi mudarat kepadamu sedikit pun. Dan jika kamu memutuskan perkara mereka, maka putuskanlah (perkara itu) di antara mereka dengan adil, sesungguhnya Allah menyukai orang-orang yang adil..."

(Surah al-Mā'idah, 5: 42)

Konteks ayat tersebut memperlihatkan keharusan menerima hujah dan tuntutan daripada golongan non Muslim dalam sesuatu urusan perundangan. Selain itu, keharusan penerimaan hujah pembelaan daripada golongan non Muslim ini juga antaranya ditetapkan berdasarkan peristiwa Khalifah 'Alī bin Abī Tāâlib yang kehilangan baju besi yang kemudiannya didapati berada di tangan seorang lelaki Yahudi. Kedua-dua mereka mengadukan hal tersebut kepada hakim negara ketika itu iaitu Syuraih. Berdasarkan keterangan dan pembuktian yang dikemukakan sepanjang sesi penghakiman berlangsung, maka baju besi itu telah diputuskan menjadi milik lelaki Yahudi tersebut. Melihatkan kepada keadilan yang dipamerkan oleh Islam walaupun lawannya ketika itu adalah pemerintah utama negara Islam, maka lelaki Yahudi itu terus memeluk Islam atas dasar kekagumannya lalu terus memulangkan semula baju besi tersebut kepada khalifah 'Alī. ${ }^{13}$ Kedua-dua dalil tersebut meskipun tidak menyentuh persoalan hukum penglibatan non Muslim sebagai peguam syarie di mahkamah secara langsung, namun dalam konteks semasa, pelaksanaan tugasan dalam urusan ini kebiasaannya diwakilkan kepada pihak peguam berdasarkan kredibiliti dan pengalaman yang dimiliki oleh mereka berkaitan prosedur perbicaraan di mahkamah. ${ }^{14}$

Penglibatan pihak non Muslim sebagai wakil dalam urusan pembelaan dan pendakwaan (dalam konteks ini sebagai peguam syarie) dibincangkan secara khusus oleh para sarjana Muslim berdasarkan kontrak al-wakālah bi al-khușümah. Kontrak ini merujuk kepada akad penyerahan kepada individu tertentu untuk menggantikan dirinya dalam membuat sebarang tuntutan, pendakwaan, pembelaan dan pembuktian di mahkamah. ${ }^{15}$ Dalam terma perundangan, peguam syarie merujuk kepada seseorang yang mewakili orang lain dalam urusan pendakwaan di hadapan hakim syarie baik dalam

13 'Abd al-Mun'im al-Hashīmī, Mashāhīr al-Qudāh (Bayrūt: Dār Ibn Kathīr, 1988), 42-46.

14 Taqwa Zabidi, 'Hukum Melantik Orang Bukan Islam sebagai Peguam Syarie', 202.

15 'Abd al-Karīm Muḥammad al-Ṭayr, Ahkē̄m al-Muhāmī fì al-Fiqh al-Islāmī: Dirāsah Muqāranah (t.t.p.: t.p., 2007), 137. 
sesuatu prosiding mahkamah atau perkara yang berhubung dengan kes yang dipertikaikan. ${ }^{16}$ Arahan Amalan No. 4 Tahun 2002 (Etika Peguam Syarie) mendefinisikan peguam syarie sebagai:

"Seseorang berkelayakan yang diterima sebagai Peguam Syarie di bawah (peruntukan undang-undang yang sedia ada...) dan termasuklah mana-mana Pendakwa Syarie, dan mana-mana orang yang dilantik di bawah seksyen 3(2) Akta Bantuan Guaman 1971, Akta 26..."

Hal ini menujukkan kepentingan peranan seseorang peguam syarie dalam membantu melancarkan proses perjalanan pentadbiran di Mahkamah Syariah. Dalam membicarakan persoalan penglibatan non Muslim sebagai peguam syarie pula, para fuqaha secara dasarnya mengharuskan keterlibatan mereka sebagai wakil pembelaan dan pendakwaan di mahkamah meskipun wujud beberapa perbezaan dalam kalangan mereka berhubung aspek teknikal. Para fuqaha Hanābilah dan Shāfi'iyyah mengharuskan penglibatan non Muslim sebagai wakil dalam urusan perundangan tanpa mengambil kira status agama mereka selagi mana urusan yang dikendalikan itu tidak melibatkan perkara yang khusus berkaitan agama Islam. ${ }^{17}$ Fuqaha Mālikiyyah hanya melarang perwakilan non Muslim dalam transaksi jual beli serta tuntutan hutang kerana mereka disifatkan tidak memiliki kelayakan yang sempurna dalam urusan tersebut. ${ }^{18}$ Fuqaha Hanafiyyah pula mengharuskan perwakilan kafir dhimmī sahaja dalam setiap urusan secara mutlak kerana kedudukan mereka dalam negara yang sama dengan orang Islam turut memberikan mereka hak yang sama seperti orang Islam. ${ }^{19}$ Ibn Qudāmah dalam merumuskan pandangan fuqaha berkaitan isu ini menyatakan:

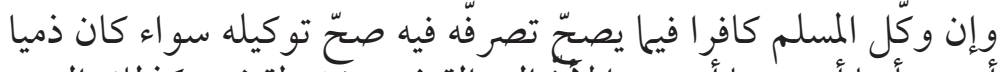

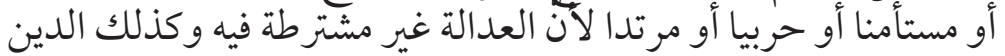

16 Ain Mawaddah Mohd Adanan, 'Peranan Peguam Syarie dalam Mengendalikan Kes Murtad dalam Kalangan Mualaf: Suatu Penilaian' (Disertasi Sarjana, Jabatan Syariah dan Undang-Undang Akademi Pengajian Islam Universiti Malaya, Kuala Lumpur, 2015), 50.

17 Muhammad bin Khātịb al-Sharbīn̄̄, Mughnī al-Muhtāj ila Ma 'rifah Ma 'ānī Alfāz al-Minhāj, vol. 2 (Bayrūt: Dār Ma'rifah, 1997), 283. Lihat juga 'Abd Allah bin Aḥmad bin Muḥammad bin Qudāmah al-Maqdīsīe al-Mughnī, vol. 7 (Riyāộ: Dār 'Ảlim al-Kutub, 1997), 237.

18 Lihat Muhammad bin Aḥmad bin Juzay al-Kalbī, al-Qawānīn al-Fiqhiyyah fi Talkhīs Madhhab al-Mālikiyyah (Bayrūt: Dār Ibn Hazm, t.t.), 593.

19 Lihat Ala' al-Dīn Abī Bakr bin Mas'ūd al-Kasānī, Badā 'i ' al-Sanā 'i ' fì Tartīb alSharā' 'i', vol. 7 (Bayrūt: Dār al-Kutub al-'Ilmiyyah, 2003), 433. 
"Sesungguhnya jika seorang Muslim mewakilkan kepada seorang kafir sesuatu urusan yang diharuskan padanya, maka sah perwakilan tersebut sama ada kafir tersebut dhimmī, musta'min, harbī mahupun murtad kerana syarat keadilan tidak terpakai ke atasnya, begitu juga agama..." 20

Keharusan ini diberikan kerana secara prinsipnya peranan para peguam hanyalah sebagai wakil dalam mengemukakan sesuatu tuntutan hak serta pensabitan dakwaan tanpa memiliki sebarang kata pemutus. ${ }^{21}$ Hal ini kerana kuasa pemutus diletakkan di tangan para hakim yang akan membuat penilaian dan penghakiman berdasarkan bukti-bukti yang dikemukakan sepanjang proses penghujahan berlangsung sebagaimana dinyatakan dalam Arahan Amalan No. 1 Tahun 2001 Kod Etika Hakim Syarie:

\section{"Apabila seseorang Hakim Syarie berada dalam Mahkamah dan mendengar sesuatu kes, dia hendaklah melaksanakan keadilan sebagaimana yang dikehendaki oleh Hukum Syarak serta menjalankan tugas mengikut Hukum Syarak dan memberi penghakimannya berdasarkan undang-undang berkaitan".}

Maka, walaupun pihak pembelaan dan pendakwaan dibenarkan untuk mengemukakan hujah dan bukti mereka sepanjang perbicaraan sesuatu kes, namun keputusan akhir sesuatu kes itu tetap disandarkan kepada kebijaksanaan pihak hakim yang akan menganalisis dan merumuskan segala penghujahan yang dikemukakan. Sekira peguam non Muslim tersebut memberikan penghujahan yang bersifat menyeleweng dan lemah, maka sudah pastinya hujah tersebut akan ditolak oleh pihak hakim. Atas dasar itulah para fuqaha tidak melihat keterlibatan non Muslim sebagai peguam di mahkamah sebagai sesuatu menjejaskan perjalanan prosiding di mahkamah.

\section{PENGLIBATAN NON MUSLIM SEBAGAI PEGUAM SYARIE DI MALAYSIA}

Meskipun secara asasnya para fuqaha mengharuskan penglibatan dan pelantikan golongan non Muslim sebagai peguam dalam aspek perundangan di mahkamah, namun penetapan hukum berkaitan isu ini tidak boleh disandarkan kepada perspektif hukum semata-mata tanpa merujuk terlebih dahulu realiti semasa yang wujud di Malaysia. Hal ini kerana faktor tempatan (lokaliti) dan nilai budaya masyarakat semasa memainkan peranan yang penting

20 Ibn Qudāmah, al-Mughnī, vol. 7, 237.

21 Daud Muhammad, 'Peguam Syarie dalam Institusi Qada', 137. 
dalam menentukan serta menafsirkan hukum syarak. ${ }^{22}$ pihak pemerintah turut mempunyai peranan dalam menetapkan sesuatu dasar atau menguruskan sesuatu isu terutamanya membabitkan kepentingan masyarakat di bawah pentadbirannya berdasarkan kerangka al-siyāsah al-shar 'iyyah. Ibn Nujaym mendefinisikan al-siyāsah al-shar 'iyyah sebagai tindakan pemerintah dalam menetapkan sesuatu keputusan atau dasar bagi menjaga kepentingan rakyat serta berusaha menghindarkan sebarang bentuk kemudaratan daripada menimpa mereka. ${ }^{23}$ 'Abd al-Wahhāb pula memperincikan lagi konsep tersebut kepada tindakan pemerintah dalam menjalankan pentadbiran awam sesebuah negara berdasarkan prinsip menjamin kebaikan dan mengelakkan keburukan selagi mana tindakan tersebut masih berada dalam ruang lingkup keharusan syariat meskipun kurang bertepatan dengan pandangan para imam mazhab. ${ }^{24}$

Konsep ini dapat diperjelaskan lagi menerusi tindakan 'Umar 'Abd al'Azīz yang pernah memutuskan untuk meringankan syarat penerimaan saksi kepada seorang sahaja dalam urusan pembuktian kes di mahkamah ketika berada di Madinah. Namun begitu, beliau kembali menguatkuasakan keperluan dua orang saksi dalam urusan yang sama sewaktu menjadi khalifah di Damsyik setelah mendapati perbezaan akhlak dan latar belakang penduduk Syam yang berbeza dengan penduduk Madinah. ${ }^{25}$ Pemahaman dan penelitian terhadap prinsip ini penting dalam usaha mengaplikasikan kehendakkehendak syarak dalam bentuk pentadbiran berdasarkan kemaslahatan semasa demi merealisasikan objektif-objektif Syariah. Maka tindakan dan keputusan pihak pemerintah perlu berasaskan metodologi al-siyāsah al-shar'iyyah bagi memastikan kemaslahatan sebenar yang ingin dicapai itu benar-benar terlaksana. ${ }^{26}$ Peruntukan bidang kuasa ini berdasarkan kaedah yang ditetapkan oleh para ulama Usul al-Fiqh iaitu :

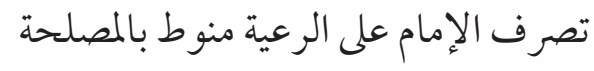

22 Abdul Karim Ali, 'Faktor-Faktor Semasa dan Setempat di Malaysia yang Boleh Mempengaruhi Penafsiran Nas Syarak dalam Menentukan Hukum,' dalam Fiqh Malaysia: Ke Arah Pembinaan Fiqh Tempatan yang Terkini, ed. Paizah Ismail \& Ridzwan Ahmad (Kuala Lumpur: Akademi Pengajian Islam UM), 59.

23 'Abd al-Fattāh 'Amrū, al-Siyāsah al-Shar'iyyah fì al-Aḥwāl al-Shakhṣiyyah (Jurdan: Dār al-Nafā'is, 1998), 18.

24 'Abd al-Wahhāb Khalaf, al-Siyāsah al-Shar 'iyyah fì al-Shu'ūn al-Dustūriyyah wa al-Khārijiyyah wa al-Māliyyah (Kuwait: Dār al-Qalam: 1988), 14.

25 Mohamad Zaidi Abdul Rahman \& Raja Hisyamudin Raja Sulung, 'Pengaruh Perubahan dalam Pembinaan Hukum Siyasah Syar'iyyah', Jurnal Syariah, 16/1 (2008): 21-22.

26 Muhammad bin Abī Bakr bin al-Qayȳ̄m al-Jawziyyah, al-Ṭuruq al-Hukmiyyah fì al-Siyāsah al-Shar'iyyah (Beirut: Dār al-Kutub al-'Ilmiyyah, 1996), 11. 


\title{
"Tindakan pemerintah terhadap rakyatnya terikat dengan maslahat..." 27
}

Kaedah ini pada dasarnya memperuntukkan ruang kepada kebijaksanaan pemerintah dalam mengendalikan urusan pentadbiran negara bagi memastikan kepentingan umum masyarakat terjaga termasuklah mengurus hubungan antara Muslim dan non Muslim dalam rangka mencapai kestabilan dan keselamatan seluruh rakyat. ${ }^{28}$

Dalam isu yang dibahaskan ini, sewajarnya kita terlebih dahulu meneliti perjalanan sistem perundangan semasa di Malaysia yang berkonsepkan dualisme di mana dua model undang-undang iaitu sivil dan Syariah dijalankan secara serentak tanpa berlaku pertindanan bidang kuasa antara satu sama lain. Perlembagaan Persekutuan telah pun memperuntukkan pembahagian bidang kuasa yang perlu dipatuhi oleh setiap mahkamah di mana Mahkamah Syariah mempunyai skop perundangan yang lebih terhad dan terbatas ${ }^{29}$ berkaitan aspek kekeluargaan, kehartaan serta jenayah melibatkan umat Islam sahaja. ${ }^{30} \mathrm{Hal}$ ini sebagaimana yang dinyatakan secara jelas dalam Jadual Kesembilan Senarai 2 Fasal 1 iaitu:

\begin{abstract}
"Kecuali mengenai Wilayah Persekutuan Kuala Lumpur, Labuan dan Putrajaya, hukum Syarak dan undang-undang diri dan keluarga bagi orang yang menganut agama Islam, termasuk hukum Syarak yang berhubungan dengan pewarisan, berwasiat dan tidak berwasiat, pertunangan, perkahwinan, perceraian, mas kahwin, nafkah, pengangkatan, kesahtarafan, penjagaan, alang, pecah milik dan amanah bukan khairat; Wakaf dan takrif serta pengawalseliaan amanah khairat dan agama, pelantikan pemegang amanah dan pemerbadanan orang berkenaan dengan
\end{abstract}

27 Jalāl al-Dīn bin 'Abd al-Raḥmān al-Suyūṭ̣̂, al-Ashbāh wa al-Naẓa'ir fi Qawā 'id wa Furū' Fiqh al-Shāfi'iyyah (Makkah: Maktabah al-Sa'ūdiyyah, 1997), 121.

28 Mohamad Zaidi Abdul Rahman, 'Mengurus Hak Beragama Bukan Muslim dari Perspektif Siasah Syar'iyyah', Jurnal Usuluddin, 36 (2012): 111.

29 Mahmud Saedon A. Othman, Institusi Pentadbiran Undang-Undang dan Kehakiman Islam (Kuala Lumpur: Dewan Bahasa dan Pustaka, 1998), 229.

30 Skop kehartaan dan jenayah juga adalah kecil kerana ruang yang lebih besar dan menyeluruh telah diperuntukkan dalam senarai persekutuan. Lihat Mahmood Zuhdi Ab. Majid, Bidang Kuasa Jenayah Mahkamah Syariah di Malaysia (Kuala Lumpur: Dewan Bahasa dan Pustaka, 2001), 210-212. Lihat juga Farid Sufian Shuaib, Powers and Juridiction of Syariah Courts in Malaysia (Petaling Jaya: Lexis Nexis Malaysia Sdn Bhd, 2008), 28-30. 
kekal agama dan khairat, institusi, amanah, khairat dan institusi khairat Islam yang beroperasi keseluruhannya di dalam negeri; adat Melayu; zakat, fitrah dan Baitulmal atau hasil agama Islam yang seumpamanya; masjid atau mana-mana tempat sembahyang awam untuk orang Islam, pewujudan dan penghukuman kesalahan yang dilakukan oleh orang yang menganut agama Islam terhadap perintah agama itu, kecuali berkenaan dengan perkara yang termasukdalam Senarai Persekutuan; keanggotaan, susunan dan tatacara bagi Mahkamah Syariah, yang hendaklah mempunyai bidang kuasa hanya ke atas orang yang menganut agama Islam dan hanya berkenaan dengan mana-mana perkara yang termasuk dalam perenggan ini, tetapi tidak mempunyai bidang kuasa berkenaan dengan kesalahan kecuali setakat yang diberikan oleh undang-undang persekutuan; mengawal pengembangan doktrin dan kepercayaan di kalangan orang yang menganut agama Islam; penentuan perkara hukum dan doktrin Syarak dan adat Melayu."

Berdasarkan teks tersebut, dapat dilihat bahawa bidang kuasa berkaitan hal ehwal agama Islam yang diperuntukkan oleh Perlembagaan Persekutuan adalah terhad dan tertumpu hanya kepada undang-undang diri (personal law) dan kesalahan-kesalahan agama sahaja. Perkara-perkara yang dinyatakan secara khusus di dalam teks tersebut sahaja yang boleh dikendalikan oleh Mahkamah Syariah manakala yang selainnya pula diletakkan di bawah bidang kuasa Mahkamah Sivil. ${ }^{31}$ Maka, berdasarkan peruntukan undang-undang yang dinyatakan, penglibatan non Muslim sebagai peguam di Mahkamah Syariah bakal mengundang suatu masalah di mana mereka tidak boleh dikenakan sebarang tindakan ${ }^{32}$ sekiranya didapati melanggar etika ${ }^{33}$ dan prosedur perundangan berkaitan Mahkamah Syariah kerana golongan tersebut tidak tertakluk kepada bidang kuasa Mahkamah Syariah. ${ }^{34}$ Penetapan tersebut sudah

31 Alias Azhar \& Mohammad Azam Hussain, 'Perluasan Skop Undang-Undang Islam di Malaysia: Aplikasi dan Implikasinya,' Jurnal Syariah 20/2 (2012): 168.

32 Peruntukan berkaitan kesalahan yang perlu dihindari oleh para peguam syarie serta tindakan yang boleh dijatuhkan ke atas mereka antaranya boleh dirujuk dalam Bahagian IV, Kaedah-Kaedah Peguam Syarie 1993 (Wilayah-Wilayah Persekutuan).

33 Setiap peguam syarie perlu melaksanakan peruntukan Arahan Amalan No. 4 Tahun 2002 yang menyatakan bahawa semua peguam syarie diwajibkan mematuhi Etika Peguam Syarie 2001. Lihat Mad Zawawi Abu Bakar, 'Isu-Isu Peguam Syarie di Malaysia', Jurnal Syariah 11 (2003): 113-114.

34 Siti Shamsiah Mad Supi, Asas dan Kerangka Perundangan Negara IslamMalaysia (Kuala Lumpur: Institut Kefahaman Islam Malaysia, 2005), 96. 
pasti mengundang ketidakadilan apabila ada pihak yang berpotensi untuk menyalahgunakan kedudukan sebagai peguam syarie tanpa boleh dikenakan sebarang tindakan. Sedangkan dalam masa yang sama peguam syarie Muslim pula perlu terikat dengan peruntukan tersebut. Perlanggaran etika dan prinsip ini boleh berlaku semasa memberi khidmat nasihat kepada anak guam, salah tafsir nas sebagai justifikasi perundangan serta sikap dan sentimen yang mungkin bersifat prejudis pada perjalanan pentadbiran Mahkamah Syariah. ${ }^{35}$ Hal ini boleh menyebabkan tindakan Perintah Menghina Mahkamah ${ }^{36}$ tidak dapat dijalankan ke atas mereka disebabkan kekangan dalam aspek perundangan ini. Maka, kebenaran kepada golongan non Muslim untuk terlibat secara langsung sebagai peguam syarie bakal mencetuskan kebimbangan berhubung kecenderungan pihak tersebut melakukan sesuatu tindakan yang menyalahi etika dan prinsip yang diamalkan di Mahkamah Syariah serta menyalahgunakan kedudukan mereka semasa pengendalian sesebuah kes.

Meskipun Perkara 74(2) memperuntukkan kuasa kepada badan perundangan negeri untuk menggubal undang-undang yang terletak dalam

35 Naziree Md. Yusof dan Aminuddin Mustaffa, 'Peguam Syarii Bukan Islam : Antara Pro dengan Kontra', 97.

36 Meskipun Mahkamah Sivil dan Mahkamah Syariah diberikan bidang kuasa untuk menjatuhkan hukuman bagi kesalahan berkaitan penghinaan mahkamah, namun sumber peruntukan tersebut adalah berbeza antara keduanya. Hal ini kerana urusan pentadbiran kedua-dua mahkamah tersebut dijalankan secara berasingan. Peruntukan undang-undang yang memberi kuasa kepada Mahkamah Syariah menghukum kesalahan penghinaan mahkamah seperti yang terkandung dalam Seksyen 229(1) Enakmen Tatacara Mal Mahkamah Syariah (Wilayah Persekutuan) Akta 1998 yang menyatakan bahawa mahkamah mempunyai bidang kuasa untuk memulakan prosiding terhadap mana-mana orang kerana menghina mahkamah dan boleh membuat perintah untuk pengkomitan seseorang selama tempoh yang tidak melebihi enam bulan atau boleh mengenakan denda tidak melebihi dua ribu ringgit. Lihat Hariani Mohamad, Zuliza Mohd Kusrin \& Mohd Zamro Muda, 'Konsep Penghinaan Mahkamah Mengikut Hukum Syarak,' (Kertas Kerja Pembentangan, Kolokium Siswazah Syariah Peringkat Kebangsaan, Masjid al-Hasanah Bandar Baru Bangi, 24 November 2015), 19.

37 Perkara 74(2) Bahagian 6 menyatakan: “Tanpa menjejaskan apa-apa kuasa untuk membuat undang-undang yang diberikan kepadanya oleh mana-mana Perkara lain, Badan Perundangan sesuatu Negeri boleh membuat undang-undang mengenai apa-apa perkara yang disebut satu persatu dalam Senarai Negeri (iaitu Senarai Kedua yang dinyatakan dalam Jadual Kesembilan) atau Senarai Bersama." 
senarai negeri, namun begitu peruntukan tersebut tetap terikat Perkara $75^{38}$ iaitu sekiranya berlaku sebarang bentuk pertentangan antara undang-undang Negeri dan undang-undang Persekutuan, maka undang-undang Negeri tersebut akan terbatal setakat yang bertentangan. Dalam hal ini, Perlembagaan Persekutuan secara jelas telah menetapkan bahawa bidang kuasa Mahkamah Syariah adalah terhad kepada orang-orang Islam sahaja. Maka, pihak kerajaan negeri tidak boleh menguatkuasakan perluasan undang-undang Syariah tersebut ke atas golongan non Muslim sama ada dalam aspek pentadbiran (administrative) mahupun perundangan (legislative) kerana ia jelas bercanggah dengan peruntukan Perlembagaan Persekutuan tersebut. Oleh itu, walaupun secara umumnya penglibatan golongan non Muslim dalam perjalanan pentadbiran Mahkamah Syariah dilihat mungkin memberikan sedikit manfaat dalam usaha memartabatkan dan meninggikan lagi kedudukan Mahkamah Syariah, namun begitu risiko yang bakal ditanggung hasil daripada penglibatan tersebut masih perlu dipertimbangkan bagi memastikan kepentingan umat Islam di Malaysia tetap dipelihara. Hal ini sebagaimana yang dijelaskan menerusi kaedah tersebut:

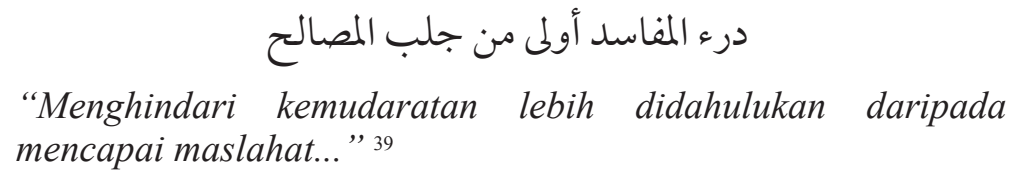

Selain itu, kefahaman yang jelas berkaitan prinsip Islam dan asas ijtihad sangat penting bagi seseorang peguam kerana pada prinsipnya seseorang peguam bukan hanya sekadar bertindak sebagai wakil dalam urusan pembelaan dan pendakwaan sahaja, namun mereka juga turut memainkan peranan penting dalam melancarkan proses keadilan serta memudahkan para hakim untuk melakukan sesuatu keputusan. ${ }^{40}$ Asas rujukan penghakiman yang berbeza antara Mahkamah Sivil dan Mahkamah Syariah juga mempengaruhi peranan yang dimainkan oleh pihak peguam. Para hakim di Mahkamah Sivil mengguna pakai doktrin Duluan Mengikat (Stare Decisis) di mana prinsip keputusan mahkamah yang lebih tinggi mengikat dan perlu dipatuhi oleh mahkamah yang lebih rendah bertujuan mewujudkan keseragaman dalam

38 Perkara 75 Bahagian 6 menyatakan: "Jika mana-mana undang-undang Negeri tidak selaras dengan sesuatu undang-undang persekutuan, maka undang-undang persekutuan itu hendaklah mengatasi undang-undang Negeri dan undang-undang Negeri itu adalah tidak sah setakat yang tidak selaras itu.

39 Jalāl al-Dīn al-Suyūṭī, al-Asybāh wa al-Naza 'ir, 87.

40 Naziree Md. Yusof dan Aminuddin Mustaffa, 'Peguam Syarii Bukan Islam: Antara Pro dengan Kontra', 88. 
keputusan yang dikeluarkan. ${ }^{41}$ Hal ini berbeza dengan asas yang digunakan oleh para hakim di Mahkamah Syariah kerana mereka pada prinsipnya hanya disarankan menghormati keputusan terdahulu daripada mahkamah yang lebih tinggi tanpa sebarang keterikatan di mana ruang berijtihad yang luas diberikan kepada mereka dalam menentukan keputusan yang dirasakan wajar dan adil. ${ }^{42}$ Arahan Amalan No. 1 Tahun 2002 secara jelas menyatakan:

"Mesyuarat telah bersetuju dan mengesahkan untuk menerima pakai keputusan berhubung isu-isu, fakta dan undang-undang yang sama atau ada persamaan yang telah diputuskan oleh mahkamah yang lebih tinggi hendaklah dihormati oleh mahkamah yang lebih rendah..."

Maka, para peguam syarie selaku pembantu para hakim dalam berijtihad memerlukan mereka sekurang-kurangnya menguasai asas hukum Islam yang diperlukan bukan sekadar kelulusan dalam sijil amalan dan perundangan Syariah semata-mata. Hal ini penting bagi mengelakkan pertikaian dan kontroversi yang mungkin dicetuskan oleh pihak tersebut hasil daripada kekeliruan dan salah faham mereka berkaitan undang-undang Islam sebagaimana yang dinyatakan oleh Rasulullah SAW:

$$
\text { أسإذا ألأمر إلى غيع الأمانة فانتظر الساعة قال كيف إضاعته الساعة يا رسول الله قال إذا }
$$

"Jika amanah telah disia-siakan, maka tunggulah kehancuran terjadi'. Seorang sahabat bertanya; 'Bagaimana maksud amanah disia-siakan wahai Rasulullah?' Baginda menjawab; 'Jika sesuatu urusan diserahkan bukan kepada ahlinya, maka tunggulah kehancuran itu..." 43

\section{USAHA PENYELESAIAN ISU PENGLIBATAN NON MUSLIM SEBAGAI PEGUAM SYARIE}

Meskipun keputusan Mahkamah Persekutuan dalam isu ini dilihat meredakan keadaan buat seketika, namun pihak-pihak yang terbabit perlu mengambil

\footnotetext{
${ }_{41}$ Abd Aziz Bari, Perlembagaan Malaysia: Teori dan Praktis (Shah Alam: Arah Pendidikan Sdn Bhd, 2008), 315.

42 Abd Aziz Bari, Perlembagaan Malaysia, 316.

43 Hadis riwayat al-Bukhārī, Kitāb al-Riqāq, Bāb Raf' al-‘Amānah, no. hadis : 6496. Lihat Muḥammad bin Ismā'̄il al-Bukhārī, Șaḥịh al-Bukhārī (Bayrūt: Dār Ibn Kathīr, 2002), 1615.
} 
beberapa langkah penambahbaikan dalam usaha memastikan peruntukanperuntukan berkaitan Mahkamah Syariah tidak boleh dieksploitasi oleh pihakpihak tertentu. Pertamanya, setiap negeri perlu mewujudkan keseragaman berkaitan syarat perlantikan sebagai peguam syarie dengan memasukkan elemen Muslim sebagai salah satu syarat yang utama ${ }^{44}$ Pihak kerajaan pernah mencadangkan mekanisme Perkhidmatan Guna Sama Pegawai Syariah bagi menyeragamkan prosedur serta syarat pengambilan Pegawai Syariah, namun hanya enam negeri sahaja yang telah bersetuju menandatangani perjanjian mekanisme tersebut sehingga menyebabkan perjanjian tersebut akhirnya terbengkalai begitu sahaja. ${ }^{45}$ Walaupun penetapan undang-undang Syariah di bawah senarai negeri telah menyebabkan kesukaran proses harmonisasi dalam penggubalan undang-undang berkaitan Islam, ${ }^{46}$ namun perbincangan yang lebih tersusun dan bersepadu antara agensi yang terlibat dilihat mampu mewujudkan jaringan kerjasama yang sistematik dalam usaha memartabatkan kedudukan undang-undang Syariah di Malaysia.

Selain itu, perlunya suatu perbincangan yang rapi dilakukan dalam menjelaskan lagi peruntukan $121(1 \mathrm{~A})^{47}$ bagi mengelakkan daripada berlakunya pertindanan dan pertembungan kuasa antara Mahkamah Sivil dan Mahkamah Syariah. Perkara ini boleh dilaksanakan dengan penubuhan satu badan panel perundingan melibatkan agensi-agensi berautoriti dalam dunia perundangan Malaysia seperti Majlis Peguam Malaysia, Persatuan Peguam Muslim Malaysia, Jabatan Kehakiman Syariah Malaysia dan sebagainya. Hal ini kerana mutakhir ini seakan menjadi kebiasaan bagi pihak-pihak tertentu mengemukakan permohonan di mahkamah Sivil bagi mencabar dan

44 Buat masa ini, negeri yang mensyaratkan secara jelas peguam syarie mestilah beragama Islam hanyalah Kelantan, Terengganu, Pahang, Wilayah Persekutuan dan Melaka. Kedah dan Johor pula menetapkan syarat yang lebih tegas iaitu peguam Syarie perlu berfahaman Ahli Sunnah wal Jamaah. Lihat Mad Zawawi Abu Bakar, 'Isu-Isu Peguam Syarie di Malaysia', 118-119.

45 Ismail Yahya, Pendakwaan dan Penyiasatan: Konsep dan Amalan (Kuala Lumpur: Institut Kefahaman Islam Malaysia, 2003), 64.

46 Mohamad Arifin et. al, Pentadbiran Undang-undang Islam di Malaysia (Selangor: Dawama Sdn Bhd, 2007), 35.

47 Peruntukan ini menetapkan bahawa Mahkamah Sivil tidak boleh mencampuri urusan dan perjalanan Mahkamah Syariah selagi mana tidak bertentangan dengan Perlembagaan Persekutuan. Lihat Irwan Mohd Subri et al., Diskusi Syariah dan Undang-Undang Siri 2 (Nilai: Fakulti Syariah dan Undang-Undang USIM, 2005), 28-29. 
membatalkan penghakiman yang telah diputuskan di Mahkamah Syariah. ${ }^{48}$ Pematuhan terhadap skop bidang kuasa setiap mahkamah dilihat penting bagi mengelakkan wujudnya sebarang elemen campur tangan bagi mempengaruhi sesuatu keputusan yang telah dikeluarkan yang akhirnya boleh mengundang perasaan tidak puas hati serta kekacauan sehingga menjejaskan ketenteraman masyarakat. Setiap isu tidak boleh dilihat dalam kerangka dan sentimen perkauman semata-mata bahkan memerlukan kompromi dan persefahaman yang baik daripada semua pihak. ${ }^{49}$ Maka, kepatuhan terhadap keputusan rundingan yang dicapai nanti dilihat memainkan peranan penting dalam memastikan keharmonian dan kestabilan institusi perundangan negara kekal terpelihara.

\section{PENUTUP}

Polemik berkaitan penglibatan non Muslim sebagai peguam syarie ini perlu diuruskan dengan baik bagi mengelakkan isu ini disalah tafsir dan dijadikan mainan modal oleh pihak-pihak tertentu. Keputusan yang dikeluarkan oleh Mahkamah Persekutuan seharusnya diterima dengan hati yang terbuka dalam usaha mengekalkan perpaduan dan keharmonian yang telah wujud sejak sekian lama dalam kalangan masyarakat Malaysia. Larangan penglibatan non Muslim sebagai peguam syarie ini sememangnya mempunyai asas menurut Perlembagaan Persekutuan. Hal ini disebabkan peruntukan perlembagaan itu sendiri yang membataskan bidang kuasa undang-undang Syariah ke atas umat Islam sahaja. Maka, halangan ini bukanlah didasarkan atas faktor sentimen semata-mata bahkan dilihat penting dalam memelihara kedaulatan undangundang negara. Oleh itu, penolakan permohonan peguam non Muslim oleh

48 Antaranya tindakan tiga orang lelaki Islam yang telah dituduh di Mahkamah Syariah Negeri Sembilan di bawah Seksyen 66 Enakmen Jenayah Syariah (Negeri Sembilan) 1992 kerana memakai pakaian perempuan atau berlagak seperti perempuan di tempat awam mengemukakan rayuan kepada pihak Mahkamah Rayuan bagi memutuskan Seksyen 66 tersebut sebagai bertentangan dengan Perlembagaan Persekutuan kerana mendiskriminasikan golongan minoriti. Tindakan ini dilakukan setelah permohonan mereka kepada pihak Mahkamah Tinggi sebelum itu ditolak. Mahkamah Rayuan pada 7 November 2014 akhirnya memutuskan bahawa Seksyen 66 tersebut adalah bertentangan dengan perlembagaan. Lihat BERNAMA, 'Mahkamah Isytihar Lelaki Berpakaian Wanita di N Sembilan bukan Jenayah', laman sesawang BH Online, http://www.bharian. com.my/node/16300, dicapai pada 05 Disember 2016.

49 Loganathan Krishnan, 'The Antithesis Between Civil Law and Islamic Law in a Pluralistic Society,' Jurnal Syariah 18/2 (2010): 409. 
Mahkamah Persekutuan seharusnya dilihat dalam konteks yang lebih luas bagi memastikan badan kehakiman negara terus dihormati.

\section{RUJUKAN}

'Abd al-Fattāh 'Amrū, al-Siyāsah al-Shar 'iyyah fì al-Ahwāl al-Shakhsiyyah (Jurdan: Dār al-Nafā'is, 1998).

'Abd al-Karīm Muhammad al-Ṭayr, Ahkām al-Muḥāmī fì al-Fiqh al-Islāmī: Dirāsah Muqāranah (t.t.p.: t.p., 2007).

'Abd al-Mun'im al-Hashīmī, Mashāhīr al-Qudāh (Bayrūt: Dār Ibn Kathīr, 1988).

'Abd al-Wahhāb Khalaf, al-Siyāsah al-Shar 'iyyah fì al-Shu'ūn al-Dustūriyyah wa al-Khārijiyyah wa al-Māliyyah (Kuwait: Dār al-Qalam, 1988).

'Abd Allāh bin Aḥmad bin Muḥammad Ibn Qudāmah al-Maqdīsī, al-Mughnī (Riyāụ: Dār 'Ālim al-Kutub, 1997).

Abdul Aziz Bari, 'Halangan-halangan Pelaksanaan Undang-undang Jenayah Islam di dalam Perlembagaan Malaysia', Jurnal Syariah, 10/1 (2002): $31-42$.

Abdul Karim Ali, "Faktor-Faktor Semasa dan Setempat di Malaysia yang Boleh Mempengaruhi Penafsiran Nas Syarak dalam Menentukan Hukum", dalam Fiqh Malaysia: Ke Arah Pembinaan Fiqh Tempatan yang Terkini, ed. Paizah Ismail \& Ridzwan Ahmad (Kuala Lumpur: Akademi Pengajian Islam UM, 2000).

Ain Mawaddah Mohd Adanan, 'Peranan Peguam Syarie dalam Mengendalikan Kes Murtad dalam Kalangan Mualaf: Suatu Penilaian’ (Sarjana Syariah, Jabatan Syariah dan Undang-Undang Akademi Pengajian Islam Universiti Malaya, Kuala Lumpur, 2015).

Ala' al-Dīn Abī Bakr bin Mas'ūd al-Kasān̄̄, Badā'i ‘ al-Sanā' ' ‘ fì Tartīb alSharā'i' (Bayrūt: Dār al-Kutub al-'Ilmiyyah, 2003).

Alias Azhar \& Mohammad Azam Hussain, 'Perluasan Skop Undang-Undang Islam di Malaysia: Aplikasi dan Implikasinya,' Jurnal Syariah 20/2 (2012): 163-184.

Aḥmad bin 'Idrīs al-Qarrāfī, 'Anwār al-Burūqfì 'Anwā' al-Furūq (Bayrūt: Dār al-Kutub al-'Ilmiyyah, 1998).

Farid Sufian Shuaib, Powers and Juridiction of Syariah Courts in Malaysia (Petaling Jaya: Lexis Nexis Malaysia Sdn Bhd, 2008).

Irwan Mohd Subri et al., Diskusi Syariah dan Undang-Undang Siri 2 (Nilai: Fakulti Syariah dan Undang-Undang USIM, 2005). 
Ismail Yahya, Pendakwaan dan Penyiasatan: Konsep dan Amalan (Kuala Lumpur: Institut Kefahaman Islam Malaysia, 2003).

Jalāl al-Dīn bin 'Abd al-Raḥman al-Suyūṭi, al-Ashbāh wa al-Naẓa 'ir fi Qawā'id wa Furū' Fiqh al-Shāfi 'iyyah (Makkah: Maktabah al-Sa'udiyah, 1997).

Loganathan Krishnan, 'The Antithesis Between Civil Law and Islamic Law in a Pluralistic Society', Jurnal Syariah, 18/2 (2010): 401-414.

Mad Zawawi Abu Bakar, 'Isu-Isu Peguam Syarie di Malaysia,' Jurnal Syariah, 11 (2003): 109-132.

Mahmood Zuhdi Ab. Majid, Bidang Kuasa Jenayah Mahkamah Syariah di Malaysia (Kuala Lumpur: Dewan Bahasa dan Pustaka, 2001).

Mahmud Saedon A. Othman, Institusi Pentadbiran Undang-undang dan Kehakiman Islam (Kuala Lumpur: Dewan Bahasa dan Pustaka, 1998).

Mohamad Arifin et al., Pentadbiran Undang-undang Islam di Malaysia (Selangor: Dawama Sdn Bhd, 2007).

Mohamad Zaidi Abdul Rahman \& Raja Hisyamudin Raja Sulung, 'Pengaruh Perubahan dalam Pembinaan Hukum Siyasah Syar'iyyah,' Jurnal Syariah, 16/1 (2008): 17-31.

Mohamad Zaidi Abdul Rahman, 'Mengurus Hak Beragama Bukan Muslim dari Perspektif Siasah Syar'iyyah,' Jurnal Usuluddin, 36 (2012): 109124.

Muhammad bin Abī Bakr Ibn al-Qayyim, al-Ṭuruq al-Hukmiyyah fí al-Siyāsah al-Shar 'iyyah (Bayrūt: Dar al-Kutub al-'Ilmiyyah, 1996).

Muhammad bin Aḥmad bin Juzay al-Kalbī, al-Qawānīn al-Fiqhiyyah fì Talkhīs Madhhab al-Mālikiyyah (Bayrūt: Dār Ibn Hazm, t.t.).

Muḥammad bin Khāțib al-Sharbīn̄̄, Mughnī al-Muhtāj ila Ma 'rifah Ma 'ān̄̄ Alfāz al-Minhāj (Bayrūt: Dār Ma'rifah, 1997).

Naziree Md. Yusof \& Aminuddin Mustaffa, 'Peguam Syarii Bukan Islam: Antara Pro dengan Kontra', Jurnal KANUN, 23/1 (2011): 84-106.

Siti Shamsiah Mad Supi, Asas dan Kerangka Perundangan Negara IslamMalaysia (Kuala Lumpur: Institut Kefahaman Islam Malaysia, 2005).

Zaharuddin Abdul Rahman, 'Bolehkah Peguam Syarie Non Muslim?', laman sesawang Zaharuddin.net, http://zaharuddin.net/senarai-lengkapartikel/3/933-bolehkah-peguam-syarie-bukan-muslim.html, dicapai pada 12 September 2016.

Zulkifli Hasan, Abdul Hamid Abdul Murad \& Arif Fahmi Mad Yusof, Amalan Guaman dan Kehakiman Syarie di Malaysia (Nilai: Kolej Universiti Islam Malaysia, 2007). 
Jurnal Syariah, Jil. 26, Bil. 1 (2018) 23-40 